\title{
Psychoactive substances: screening for brief intervention in primary health care, Rio de Janeiro/Brazil
}

\author{
Angela Abreu ${ }^{1 *}$, Maria Helena Nascimento Souza ${ }^{1}$, Rafael Tavares Jomar ${ }^{2}$, Rafaela Costa ${ }^{3}$, Pedro Parreira ${ }^{4}$, \\ Teresa Barroso ${ }^{4}$
}

From INEBRIA 12th Congress, Atlanda, GA, USA. 24-25 September 2015

\section{Background}

About $10 \%$ of the populations in urban centers all over the world misuse psychoactive substances, independently of age, gender, education level and purchasing power. The use of these substances is direct and indirectly related with a series of health problems, among which traffic accidents, aggression, clinical depressions and conduct disorders are highlighted, besides sexual risk behavior and the risk of HIV transmission due to injectable drug use and other health problems. We analyzed the profile of a population attended in the Family Health Strategy, considering the consumption of psychoactive substances in the last three months.

\section{Material and methods}

Quantitative, Cross-sectional descriptive survey, conducted in a community located in the north of Rio de Janeiro. The sample consisted of 1489 users of the Service, using a structured questionnaire (Alcohol, Smoking and Substance Involvement Screening Test). Data collection was conducted within one year. The analysis was performed with SPSS software using statistical measures appropriate (test $t$ de student and ANOVA and Pearson correlations), respectively to evaluate mean differences for two and more than two groups, Pearson correlations, using the Statistical Package Social Science (SPSS) version 22.0 and we have established a level statistical significance at $\mathrm{p}<0.05$. The ethical study procedures were represented by the approval of the Ethics Committee of the Municipal Secretaria of Health and Civil Defense of Rio de Janeiro number 132/09

\footnotetext{
* Correspondence: angelabreu@globo.com

'Public Health Nursing, Federal University of Rio de Janeiro, Brazil

Full list of author information is available at the end of the article
}

\section{Results}

The male population was prevalent in consumption over life and in the last three months, more frequently for tobacco use $56.4 \%$, alcohol $75.8 \%$, cannabis $16.9 \%$ and cocaine / crack $10.1 \%$. Religion showed as a protective factor for drug use.

\section{Conclusions}

We emphasize the relevance of the inclusion of the model of Brief Interventions, a low-cost and gentle technology in this area and in the nursing practice.

Acknowledgements

National Counsel of Technological and Scientific Development/ CNPq, Brazil

\section{Authors' details}

${ }^{1}$ Public Health Nursing, Federal University of Rio de Janeiro, Brazil. ${ }^{2}$ State University of Rio de Janeiro, Brazil. ${ }^{3}$ Federal University of Rio de Janeiro, Brazil. ${ }^{4}$ Coimbra Nursing School, Portugal.

Published: 24 September 2015

\section{References}

1. ONU: United Nations Office On Drugs And Crime/Unodc. World Drug Report. United Nations, New York; 2013.

2. Brasil. Ministério da Saúde: A política do ministério da saúde para ateníão integral a usuários de álcool e outras drogas. Brasília (DF): Ministério da Saúde; 2004

3. World Health Organization: Global Health Risks. Genebra (Swi): World Health Organization; 2009.

4. Brasil. Ministério da Saúde: Política nacional de ateníão básica. Brasília (DF): Ministério da Saúde; 2012.

5. Schneider DR, Lima DS: Implicaíões dos modelos de ateníão à dependência de álcool e outras drogas na rede básica em saúde. Psico 2011, 42(2):168-78.

6. Minto EC, Corradi-Webster CM, Gorayeb R, Laprega MR, Furtado EF: Interveníões breves para o uso abusivo de álcool em ateníão primária. Epidemiol Serv Saúde 2007, 16(3):207-20. 
7. Babor TF, Higgins-Biddle JC, Saunders JB, Monteiro MG: The alcohol use disorders identification test: guideline for use in primary care. Genebra (Swi): World Health Organization;, 2001.

doi:10.1186/1940-0640-10-S2-P1

Cite this article as: Abreu et al:: Psychoactive substances: screening for brief intervention in primary health care, Rio de Janeiro/Brazil. Addiction Science \& Clinical Practice 2015 10(Suppl 2):P1.

Submit your next manuscript to BioMed Central and take full advantage of:

- Convenient online submission

- Thorough peer review

- No space constraints or color figure charges

- Immediate publication on acceptance

- Inclusion in PubMed, CAS, Scopus and Google Scholar

- Research which is freely available for redistribution

Submit your manuscript at www.biomedcentral.com/submit
Ciomed Central 